\title{
Enhance Students' Motivation to Learn Programming through Projects
}

\author{
https://doi.org/10.3991/ijet.v15i21.16537
}

\author{
Zhanat Nurbekova, Talant Tolganbaiuly ${ }^{(凶)}$, Parassat Tazabekova, \\ Gulmira Abildinova, Bahyt Nurbekov \\ L.N. Gumilyov Eurasian National University, Nur-Sultan, Kazakhstan \\ talant2101@gmail.com
}

\begin{abstract}
This article presents the results of a pedagogical experiment when teaching microcontroller programming. The pedagogical experiment was conducted at the Faculty of Information Technology of the L.N. Gumilyov Eurasian National University in the form of project-based seminars on the Arduino platform (2017-2020). The experiment was attended by 88 first-year IT students. Our goal in this study is to verify the proposed hypothesis on the use of the project-based learning method in teaching microcontroller programming. In the process of conducting a pedagogical experiment, we divided our students into 2 groups: control and experimental. The training of both groups was carried out according to one curriculum, but using different methods. In the control group, traditional teaching methods and learning tools were used, and in the experimental group, we used the technology of project-based learning. As assessment criteria, we took the test tasks "pre-test" and "post-test" that we developed and conducted a survey for the control and experimental groups. We used statistical methods to confirm or refute the proposed hypothesis of our research, that is, at the end of the pedagogical experiment to get an informed decision about the difference and coincidence of the obtained data.
\end{abstract}

Keywords - Project-based learning, Arduino microcontroller, projects, programming microcontrollers

\section{$1 \quad$ Introduction}

Modern technology is developing with great speed and is being implemented in almost all areas of our lives. At the same time, the requirements of employers are growing to keep up with the times, students need to study diligently, develop themselves, especially in the field of computer science and engineering. Over the past few years, most of the world's universities have been actively using the project method for training relevant personnel in information technology with the aim of increasing students' motivation to study, develop teamwork skills and apply knowledge in practice [1-6].

When studying the disciplines of information technology (programming, programming of microcontroller, educational robotics, etc.) it is necessary to use a pro- 
ject-based learning method, since the basis of the development of information systems, automated devices, robots are "design" [7].

During the study, we developed a project-based learning technology for the course "Microcontroller Programming". Working on projects using microcontrollers enables a teacher to implement educational goals by attracting knowledge from other areas (programming, physics, mathematics, mechatronics, electronics and others), to introduce creativity into the educational process, and also contributes to the formation of key competencies among students [8-14].

Our goal in this study is to verify the proposed hypothesis on the use of the projectbased learning method in teaching Microcontroller Programming:

$\mathrm{H}_{1}$ : if Microcontroller Programming teaching is based on the application of projectbased learning technology, it will provide quality training and increase the motivation of students to study.

\section{Methods}

The pedagogical experiment was carried out during the educational practice of students of the Faculty of Information Technology of the L.N. Gumilyov Eurasian National University (2017-2020). The experiment was attended by first-year students of IT specialities.

In the process of conducting a pedagogical experiment, we divided our students into two groups: control and experimental. The training of both groups was carried out according to one curriculum, but using different methods. In the control group (CG), traditional teaching methods and learning tools were used, and in the experimental group (EG), we used the technology of project-based learning for the course "Microcontroller Programming".

As assessment criteria, we took the test tasks "pre-test" and "post-test" that we developed and conducted a survey for the control and experimental groups. Test tasks "pre-test" were designed to determine the initial state of students' knowledge of the discipline: the basics of "Programming and Algorithmization". Test tasks "post-test" were selected based on the key points of the training program of the Microcontroller Programming [15]. Rating scale - from 0 to $100 \%$.

The technology of project-based learning was developed based on the analysis of the following scientific, methodological and regulatory documents [16-25].

The technology of project training in Microcontroller Programming consists of three main blocks: "Project Organization", "Project Implementation" and "Project Evaluation".

According to the first block "Project Organization", initially the project group was formed taking into account interpersonal relations and interests of students. When forming a project group, depending on the specifics of the project, the composition of the project groups was determined: project manager, engineer and programmer. It should be noted that one of the main features of the design work is that each student gets the opportunity to analyze the problem, propose their solutions, and perform certain functions. 
Next, a selection of training projects was carried out taking into account the features of the basic components of microcontrollers. As the training platform, we chose the Arduino microcontroller. The distinctive features of the Arduino microcontroller are the simple and understandable programming environment Arduino IDE, crossplatform and open-source software [26-28]. Consequently, projects based on the Arduino microcontroller were proposed: "Smart light", "Smart traffic light", "Smart window", "Smart fan", "Smart parking", "Smart home". Projects were developed on the principle of "from simple to more complex" (figure 1) [8].

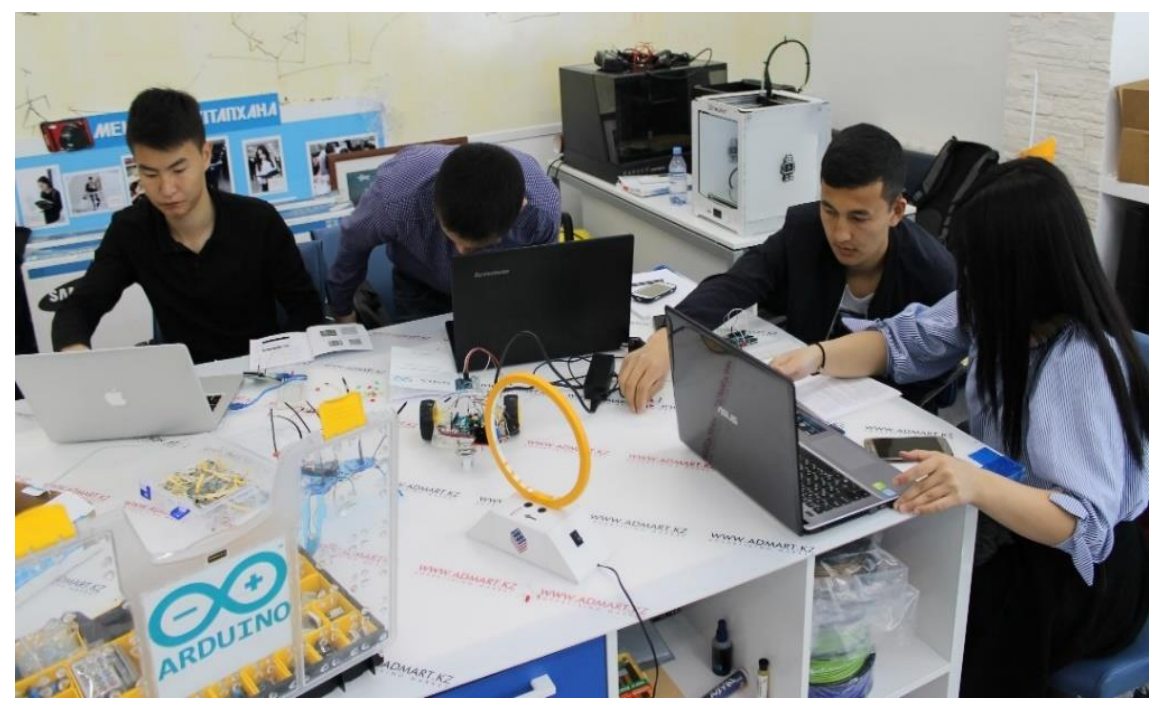

Fig. 1. Training projects

Consider the second block of the structural model of the organization of projectbased learning of microcontrollers programming named "Project Implementation". Project participants study the capabilities of the Arduino microcontroller and select the necessary details for the implementation of the project. Testing and debugging of software and hardware were carried out in this block.

"Project Evaluation" is the final block of work of the structural model for organizing the project-based learning instruction in programming microcontrollers. The preparatory stages of project protection include: creating a passport and project presentations. Students together with the teacher prepared a project passport. This document contains the main characteristics of the project. The key requirement in preparing the project passport is a detailed description of the work performed by each student in the project team. Upon completion of the preparation of the project passport, the project teams went on to develop project presentations for protection before the public. 


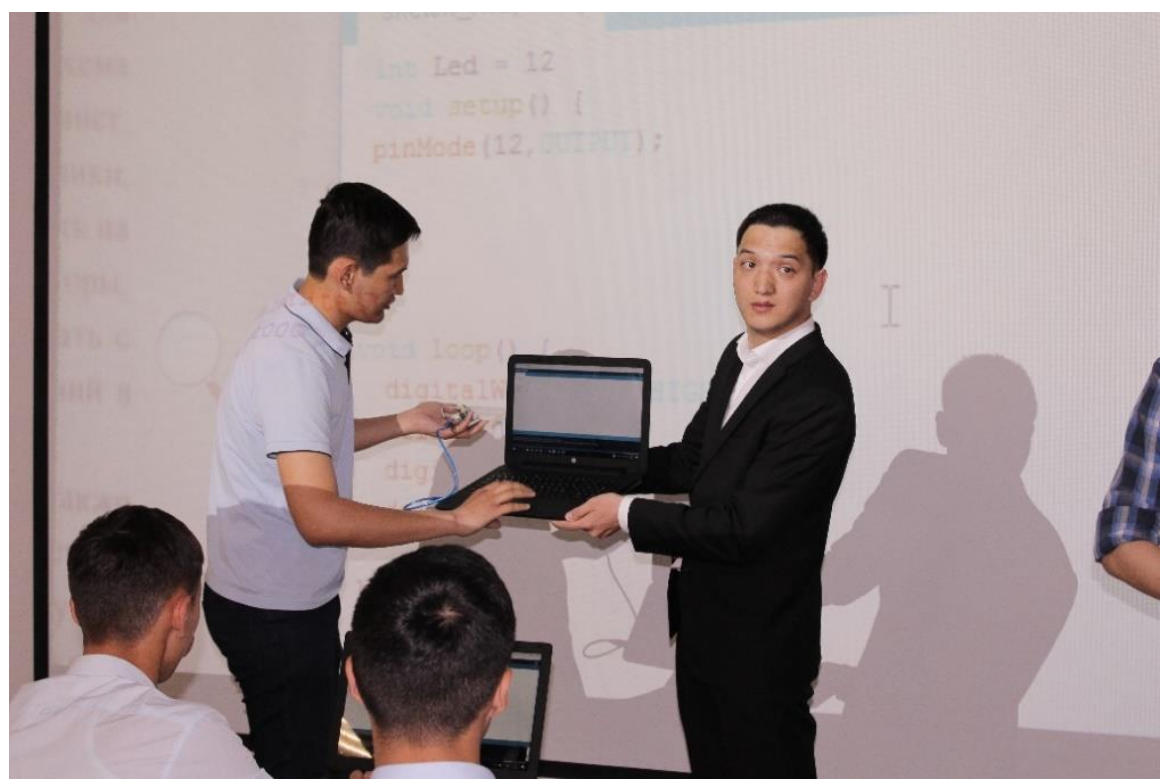

Fig. 2. Fragment of the presentation project by students

Especially for the jury (teachers) before the defense of the project, checklists were issued "Project Evaluation". During the defense, the checklists were filled out and after that the arithmetic mean was calculated from the calculation of the points given for each position. Based on the setpoints, a general assessment of the design work of students is formed [29].

\section{$3 \quad$ Results and Discussions}

The main goal of the experiment was to check the scientific hypothesis of the study in practice and evaluate the applied methodology.

We used statistical methods to confirm or refute the proposed hypothesis of our research, that is, at the end of the pedagogical experiment to get an informed decision about the difference and coincidence of the obtained data.

Our work on the confirmation or refutations of the proposed research hypothesis consisted of the following stages:

1. Calculation of the empirical value of the criterion, based on the results of "pretest" and "post-test" of the experimental and control groups;

2. The empirical value of the criterion is compared with the critical value of the criterion (0.05 significance level). The reliability of differences in the characteristics of the experimental and control group members will be equal to $95 \%$ if the obtained empirical value of the criterion is greater than the critical value [30]. 
In our situation, we chose Pearson's uniformity criterion $\chi^{2}$, since the number of gradations in the ordinal scale (different points) is more than three $(\mathrm{L}=4)$ and the sample size includes 88 students.

We systematized the results of "pre-test" and "post-test" tasks on an ordinal scale (table 1). The obtained students' scores were divided by levels of knowledge into percentage terms: $\mathrm{L}=4(100-90 \%, 89-75 \%, 74-50 \%, 49-0 \%)$.

Table 1. The results of measurements of the level of knowledge in the control and experimental groups before and after the experiment

\begin{tabular}{|c|c|c|c|c|}
\hline $\begin{array}{c}\text { Point } \\
(\%)\end{array}$ & $\begin{array}{c}\text { CG pre-test } \\
\text { (students) }\end{array}$ & $\begin{array}{c}\text { EG pre-test } \\
\text { (students) }\end{array}$ & $\begin{array}{c}\text { CG post-test } \\
\text { (students) }\end{array}$ & $\begin{array}{c}\text { EG post-test } \\
\text { (students) }\end{array}$ \\
\hline $100-90$ & 1 & 0 & 2 & 7 \\
\hline $89-75$ & 9 & 3 & 4 & 17 \\
\hline $74-50$ & 19 & 19 & 27 & 17 \\
\hline $49-0$ & 15 & 22 & 11 & 3 \\
\hline Total: & 44 & 44 & 44 & 44 \\
\hline
\end{tabular}

During the research, a web application was developed (in the Python Programming language and Django framework) for statistical analysis. Using the web application, we calculated the empirical values of the $\chi^{2}$ criterion for all compared samples of the $\chi^{2}$ emp experimental and control groups (table 2).

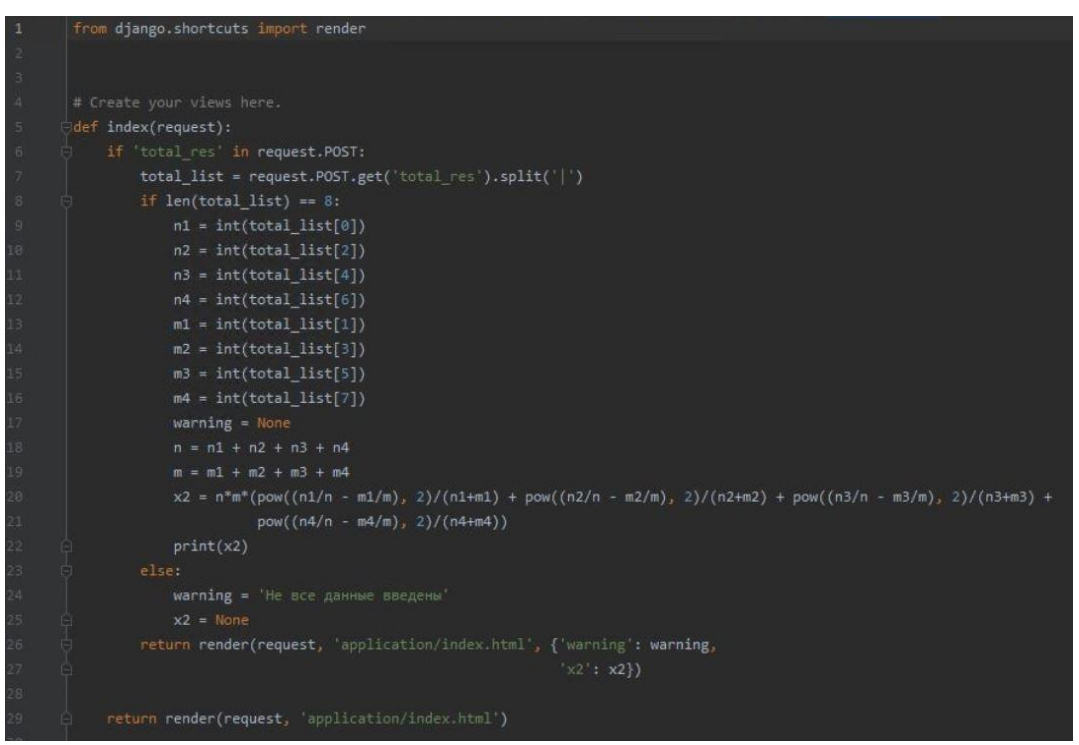

Fig. 3. Program code of the developed web application 


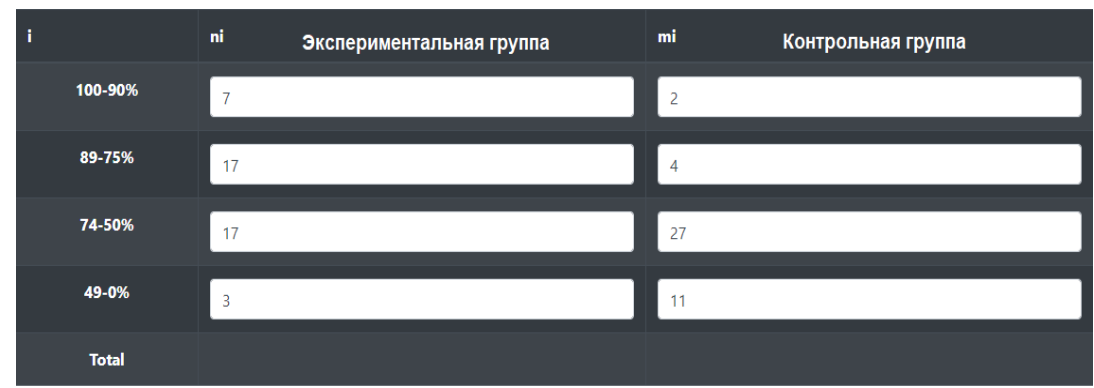

Run $Х 2 \ni \mathrm{M}=17.66$

Fig. 4. Web application interface

Table 2. The empirical values of the criterion $\chi^{2}$ for all compared samples $\chi_{\mathrm{emp}}^{2}$ of the experimental and control groups

\begin{tabular}{|l|c|c|c|c|}
\hline & CG pre-test & EG pre-test & CG post-test & EG post-test \\
\hline CG pre-test & 0 & 4,64 & 4,26 & 15,07 \\
\hline EG pre-test & 4,64 & 0 & 7,20 & 31,35 \\
\hline CG post-test & 4,26 & 7,20 & 0 & 17,66 \\
\hline EG post-test & 15,07 & 31,35 & 17,66 & 0 \\
\hline
\end{tabular}

Table 3 shows the critical values of the $\chi^{2}$ criterion for the significance level $\alpha=$ 0.05 . Our critical value of the criterion $\chi^{2}$ is $\chi_{0.05}^{2}=7,82(\mathrm{~L}=4, \mathrm{~L}-1$, therefore, $\mathrm{L}=3)$.

Table 3. The critical value of the criterion $\chi^{2}$ for the significance level $\alpha=0.05$

\begin{tabular}{|c|c|c|c|c|c|c|c|}
\hline $\mathbf{L}-\mathbf{1}$ & $\mathbf{1}$ & $\mathbf{2}$ & $\mathbf{3}$ & $\mathbf{4}$ & $\mathbf{5}$ & $\mathbf{6}$ & $\mathbf{7}$ \\
\hline$\chi_{0,05}^{2}$ & 3,84 & 5,99 & 7,82 & 9,49 & 11,07 & 12,59 & 14,07 \\
\hline
\end{tabular}

The comparison of data showed that before the pedagogical experiment, the characteristics of all compared samples coincide with the level of 0.05 (table 2), the null hypothesis (H0) was confirmed, and all empirical values of $\chi^{2}$ were less than the critical value, except the results of "post-test".

Since $\chi^{2}$ emp $=17,66>7,82=\chi_{0.05}^{2}$, then "reliability of differences of the characteristics of the experimental and control groups after the end of the experiment is $95 \%$ ".

Table 4. Descriptive statistics of the number of correctly solved problems in the control group and the experimental group after the pedagogical experiment

\begin{tabular}{|c|l|c|c|}
\hline № & \multicolumn{1}{|c|}{ Statistical data } & CG & EG \\
\hline 1 & Arithmetic mean & 7,9 & 10,5 \\
\hline 2 & Median & 8 & 10,5 \\
\hline 3 & Mode & 9 & 10 \\
\hline 4 & Sample variance & 8 & 4,3 \\
\hline 5 & Standard deviation & 2,8 & 2,1 \\
\hline 6 & Sample size & 44 & 44 \\
\hline
\end{tabular}


Table 4 shows the results of the descriptive statistics of the conducted pedagogical experiment. Based on the data in table 4, it can be seen that the results of the experimental group are considerably higher than the results of the control group, namely, the arithmetic mean value of the experimental group is higher by 2.6 points, mode and median by 2.5 points and 1, respectively. The considerable difference between the experimental and control group was in the amount of data dispersion around the arithmetic mean value, the sample variance of the experimental group was halved compared to the control group.

On the bases of statistical processing of the pedagogical experiment data, it is proved that the project-based learning technology of Microcontroller Programming provides high-quality training and increases students' motivation to learn.

To further test our H1 hypothesis, we conducted a correlation analysis of students' performance.

Our pedagogical experiments were conducted in the interim of the first and second year of the Faculty of Information Technology. Following the results of the pedagogical experiment, we decided to study the academic performance of our students, namely, the results of assessments of disciplines in the area of "Programming Fundamentals" of the first (pre-requisite) and second (post-requisite) courses, in order to understand how our pedagogical influences had affected the further training of students in the given direction (figures 5-6).

As it is seen from the figures below, we have the following indicators: "prerequisite" assessment of disciplines in the area of "Program Fundamentals" for the first year; "pre-test" assessment of entrance testing before pedagogical research; "post-test" assessment of output testing after pedagogical research; "post requisite" assessment of disciplines in the area of "Programming Fundamentals", "Objectoriented programming languages" for the second year.

Generally, the dynamics of students' assessment who took part in our pedagogical experiments are positive. For example, students' performance in the speciality of "Computer technology" (CT) in the experimental and control group increased by 7 points. At the same time, the results of the "post-test" assessment of the output testing of the students of experimental group after the pedagogical research increased by 50 points. 


\section{Control groups}

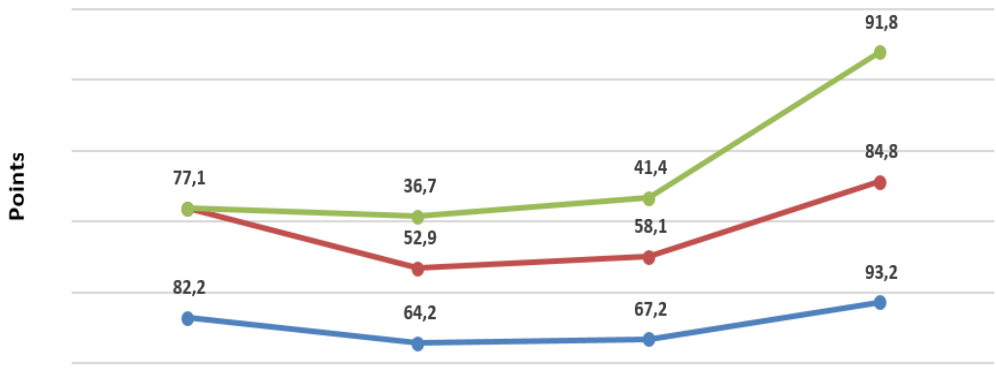

\begin{tabular}{|c|c|c|c|c|}
\cline { 2 - 5 } \multicolumn{1}{c|}{} & 1 & 2 & 3 & 4 \\
\hline$\sim$ CSE & & 36,7 & 41,4 & 91,8 \\
\hline$\multimap$ CT & 77,1 & 52,9 & 58,1 & 84,8 \\
\hline$\multimap$ CSIS & 82,2 & 64,2 & 67,2 & 93,2 \\
\hline
\end{tabular}

Fig. 5. The results of assessments in the control group

\section{Experimental groups}

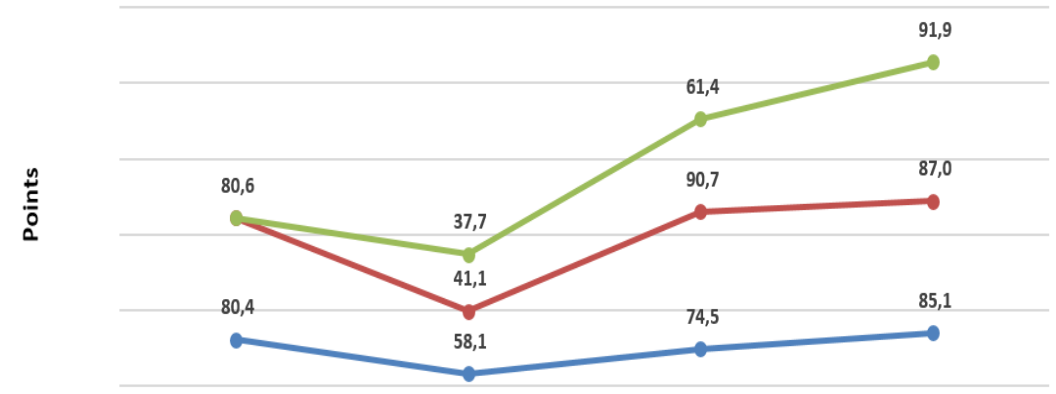

\begin{tabular}{|c|c|c|c|c|}
\cline { 2 - 5 } \multicolumn{1}{c|}{} & 1 & 2 & 3 & 4 \\
\hline$\multimap$ CSE & & 37,7 & 61,4 & 91,9 \\
\hline$\multimap$ CT & 80,6 & 41,1 & 90,7 & 87,0 \\
\hline$\multimap$ CS & 80,4 & 58,1 & 74,5 & 85,1 \\
\hline
\end{tabular}

Fig. 6. The results of assessments in the experimental group

Also, the indicators of students of the experimental and control groups of the speciality "Computer Science and Information Security" (CSIS) increased by 11 and 4.7 points, accordingly. In this group, a similar situation is as in the first one, the results of the "post-test" assessment of the output testing of pedagogical research have increased significantly.

Positive dynamics of the experiment results are observed among students of the experimental and control group of the speciality of "Computer Science in Education" 
(CSE). It should be noted that in these groups there is no estimated data for the first year, since students of this speciality did not have disciplines in the area of "Programming" in freshman year.

Based on this, it is logical to assume that the use of the project-based learning method in teaching Microcontroller Programming has a positive impact on the cognitive level of students' motivation, and on further training in this area.

\section{Conclusion}

Summing up the results of the research, on the bases of statistical processing of the pedagogical experiment data, it is proved that the technology of project-based learning for the course "Microcontroller Programming" provides students' highquality training. The proposed hypothesis was confirmed.

Moreover, students were more motivated to study IT disciplines, in particular on "Microcontroller Programming", despite the fact that they had a low initial level of knowledge in the area of "Programming and Algorithmization".

In the process of applying the given technology, conditions are created that are fully correspond to the situations of real professional activity. Students have gained extensive experience and skills in solving complex problems with the design of the implementation of the plan, as well as distributing functions among the members of the project team.

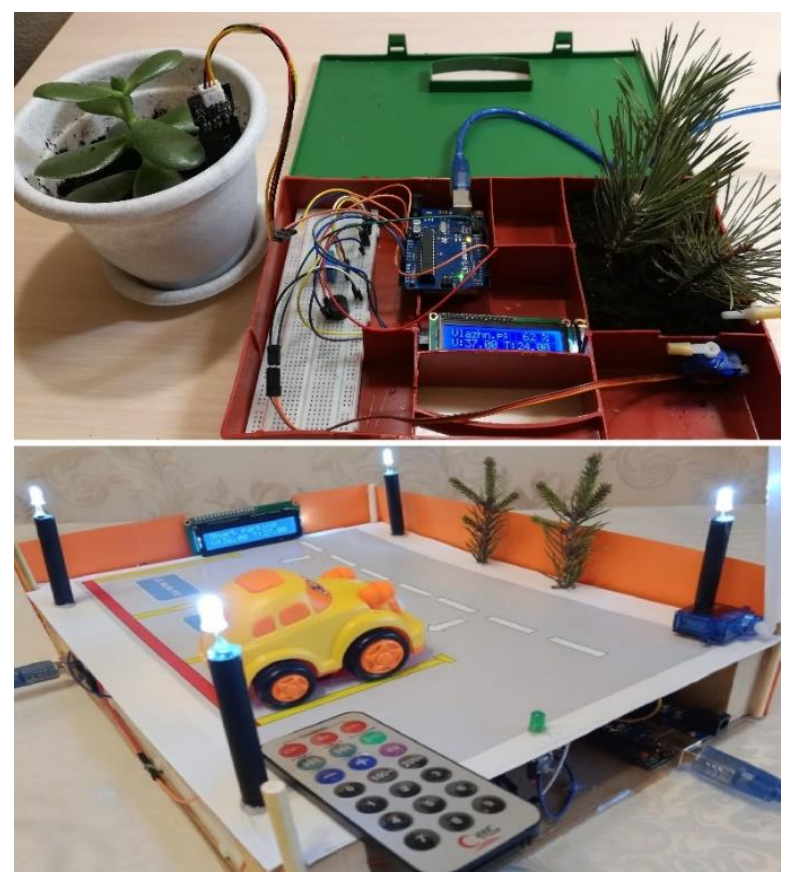

Fig. 7. Training projects developed as part of our seminars 


\section{$5 \quad$ References}

[1] Michal Růžička, Michal Rejthбrek, Štěpøn Major, Project-based Learning in Basic Course of Technical Physics: Computer-controlled Experiments and Agros2D Modeling, international journal of education and information technologies, Volume 11, 2017.

[2] Marнa del Carmen Currós-Francos, Javier Diz-Bugarнn, Juan Ramyn Garcнa-Vila, and Angel Orte-Caballero,Cooperative Development of an Arduino-Compatible Building Automation System for the Practical Teaching of Electronics, IEEE REVISTA IBEROAMERICANA DE TECNOLOGIAS DEL APRENDIZAJE, VOL. 9, NO. 3, AUGUST 2014. https://doi.org/10.1109/rita.2014.2340015

[3] F. Bouquet and J. Bobroff, M. Fuchs-Gallezot and L. Maurines, Am. J. Phys. Project-based physics labs using low-cost open-source hardware, 85 (3), American Association of Physics Teachers, http://aapt.org/ajp, March 2017. https://doi.org/10.1119/1.4972043

[4] Pablo Marthn-Ramos, Student2student: Arduino Project-based Learning, Fourth International Conference on Technological Ecosystems for Enhancing Multiculturality TEEM'16, Salamanca, Spain, November 02 - 04, 2016. https://doi.org/10.1145/3012430.3 $\underline{012500}$

[5] A. Garrig6s, D. Marroqui, J. M. Blanes, R. Gutierrez, Designing Arduino electronic shields: experiences from secondary and university courses, 2017 IEEE Global Engineering Education Conference (EDUCON), Athens, Greece, 25-28 April 2017. https:// doi.org/10.1109/educon.2017.7942960

[6] Dr. Jose Antonio Riofrio, Teaching Undergraduate Introductory Course to Mechatronics in the Mechanical Engineering Curriculum Using Arduino, American Society for Engineering Education, 120 ASEE Annual Conference \& Exposition, 2013. https://doi.org/ $10.18260 / 1-2--22539$

[7] L.V. Sidorova, Ispolzovanie metoda proektov pri izuchenii informacionnyh tehnologii. Vestnik Bryanskogo gosudarstvennogo universiteta, 2010.

[8] Zh.K. Nurbekova, T. Tolganbaiuly, Results of experimental-experimental work in the teaching of programming of microrobots, Kazakh national pedagogical university after Abai, Bulletin Series «Pedagogical sciences», №1(61), Almaty, 2019. https://doi.org/10.3 1489/2020ch2/105-112

[9] Am. J. Phys. J. G. King, On physics project laboratories, 34(11), 1058-1062, 1966.

[10] Am. J. Phys. J. I. Shonle, "Project laboratory in electricity and magnetism", 35(9), 792796, 1967.

[11] Educ. Psychol. P. C. Blumenfeld et al., Motivating project-based learning: Sustaining the doing, supporting the learning, 26(3-4), 369-398, 1991. https://doi.org/10.1207/s15326985 ep2603\&4_8

[12] J. Eng. Educ. M. J. Prince and R. M. Felder, Inductive teaching and learning methods: definitions, comparisons, and research bases, 95(2), 123-138, 2006. https://doi.org/10.10 02/j.2168-9830.2006.tb00884.x

[13] M. Holm, Rivier Acad. J. Project-based instruction: A review of the literature on effectiveness in prekindergarten through 12th grade classrooms, 7(2), 1-13, 2011

[14] Dossier d'actual. Veille Anal. C. Reverdy, Des projets pour mieux apprendre?82, 1-24, 2013.

[15] Zh. Nurbekova, N. Tokzhigitova, B. Nurbekov, G. Jarassova, Multi-criteria Assessment of Students' Study Achievements in Visual Programming. Man In India, 97 (13): 483-509, January 2017.

[16] ISO/IEC 12207:2008 "System and software engineering - Software life cycle processes", 2008. https://doi.org/10.3403/30236650 
[17] ISO 21500:2012 - Guidance on project management, 2012.

[18] A Guide to the Project Management Body of Knowledge - Fifth edition, ISBN 978-1935589-67-9, Project Management Institute, 2013.

[19] Sahil Barjtya, Ankur Sharma, Usha Rani, A detailed study of Software Development Life Cycle (SDLC) Models, International Journal of Engineering And Computer Science ISSN:2319-7242, Volume 6 Issue 7, Page No. 22097-22100, July 2017.

[20] Marco Antonio Carvalho Pereiraa, Maria Auxiliadora Motta Barretoa, Marina Pazetia, Application of Project-Based Learning in the first year of an Industrial Engineering Program: lessons learned and challenges, aUniversidade de Кго Paulo, Lorena, SP, Brasil, Print version ISSN 0103-6513On-line version ISSN 1980-5411, 2017.

[21] Dr. Afsaneh Minaie, Dr. Reza Sanati-Mehrizy, Capstone Projects in a Computer Engineering Program Using Arduino, American Society for Engineering Education, Paper ID \#15299, ASEE's 123rd Annual, conference\&Exposition, june 26-29, 2016. https://doi. org/10.18260/p.26446

[22] Petre Lucian Ogrutan, Increasing Students' Interest by Encouraging them to Create Original Lab Projects, TEM Journal. Volume 6, Issue 4, Pages 653-659, ISSN 2217-8309, DOI: 10.18421/TEM64-02, November 2017.

[23] Kun Ma, Hao Teng, Lixin Du, and Kun Zhang, Project-Driven Learning-by-Doing Method for Teaching Software Engineering Using Virtualization Technology, International Journal of Emerging Technologies in Learning. Volume 9, Issue 9: "Blended Learning", 26-31, 2014. https://doi.org/10.3991/ijet.v9i9.4006

[24] S. Jacques, S. Bissey and A. Martin. Multidisciplinary Project Based Learning Within a Collaborative Framework A Case Study on Urban Drone Conception. International Journal of Emerging Technologies in Learning. Vol 11, No 12. 36-44, 2016. https://doi.org/10.39 91/ijet.v11i12.5996

[25] Yu.Yu. Kovalyova, A.V. Soboleva, A.T. Kerimkulov. Project Based Learning in Teaching Communication Skills in English as a Foreign Language to Engineering Students. International Journal of Emerging Technologies in Learning. Vol 11, No 04.253-156, 2016. https://doi.org/10.3991/ijet.v11i04.5416

[26] Banzi, M., Getting started with Arduino: The Open Source Electronics Prototyping Platform. Maker Media, Inc. \& Shiloh, M., 2014.

[27] Official website of Arduino: https://www.arduino.cc/

[28] Zh.K. Nurbekova, T. Tolganbaiuly, the selection of the learning environment programming micro-robots in high school, XXIV International Scientific Conference "Actual Scientific Research in the Modern World", State Higher Educational Institution "PereyaslavKhmelnitsky State Pedagogical University named after Grigory Skovoroda, Ukraine, Pereyaslav-Khmelnitsky, 2017. https://doi.org/10.25313/2520-2294-2019-7-5117

[29] Zh.K. Nurbekova, T. Tolganbaiuly, B. Nurbekov, A. Sagimbayeva, Zh.Kazhiakparova; Project-based learning technology: An Example in programming microcontrollers, International Journal of Emerging Technologies in Learning (iJET), Vol 15, No 11, 2020. https://online-journals.org/index.php/i-jet/article/view/13267 https://doi.org/10.3991/ijet. v15i11.13267

[30] D.A. Novikov, Statisticheskie metody v pedagogicheskih issledovaniah, M.: MZ-Press, page 67, 2004. 


\section{Authors}

Zhanat Nurbekova is a Doctor of Pedagogical Sciences, professor, Director of the Institute of Digitalization, L.N.Gumilyov Eurasian National University, 010000, NurSultan, Kazakhstan, nurbekova_zhk@enu.kz

Talant Tolganbaiuly is a senior engineer, Department of Informatics and Information Security, L.N.Gumilyov Eurasian National University, 010000, NurSultan, Kazakhstan, talant2101@gmail.com

Parassat Tazabekova is a doctoral Student, Department of Computer Science, Information Technologies Faculty, L.N.Gumilyov Eurasian National University, 010000, Nur-Sultan, Kazakhstan, para2890@ mail.ru

Gulmira Abildinova is a candidate of pedagogical sciences, associate professor, L.N.Gumilyov Eurasian National University, 010000, Nur-Sultan, Kazakhstan, gulmira_2181@mail.ru

Bahyt Nurbekov is a Doctor of Pedagogical Sciences, professor, Faculty of Mechanics and Mathematics, L.N.Gumilyov Eurasian National University, 010000, Nur-Sultan, Kazakhstan, b_zh_nur@mail.ru

Article submitted 2020-06-24. Resubmitted 2020-07-19. Final acceptance 2020-07-21. Final version published as submitted by the authors. 